\title{
Periapical lesions in intentionally modified teeth in a skeletal sample of enslaved Africans (Lagos, Portugal)
}

\begin{tabular}{|r|l|}
\hline Journal: & International Journal of Osteoarchaeology \\
\hline Manuscript ID & OA-15-0128.R2 \\
\hline Wiley - Manuscript type: & Research Article \\
\hline Complete List of Authors: & $\begin{array}{l}\text { Rufino, Ana; University of Coimbra, Department of Life Sciences } \\
\text { Ferreira, Maria Teresa; University of Coimbra, Department of Life } \\
\text { Sciences; } \\
\text { Wasterlain, Sofia; University of Coimbra, Department of Life Sciences }\end{array}$ \\
\hline Keywords: & $\begin{array}{l}\text { Dental modifications, Periapical cyst, Granuloma, Dental infection, African } \\
\text { slaves, 15th-17th centuries }\end{array}$ \\
\hline
\end{tabular}

\section{SCHOLARONE ${ }^{\text {M }}$}

Manuscripts 


\section{Periapical lesions in intentionally modified teeth in a skeletal sample of enslaved Africans (Lagos, Portugal)}

\section{A. I. Rufino ${ }^{a}$, M. T. Ferreira ${ }^{\text {a, b, c, d }}$, S. N. Wasterlain ${ }^{\text {a, b, c, d,* }}$}

${ }^{\text {a }}$ Centro de Ecologia Funcional, Department of Life Sciences, University of Coimbra, Coimbra, Portugal

${ }^{\mathrm{b}}$ Laboratory of Forensic Anthropology, Department of Life Sciences, University of Coimbra, Coimbra, Portugal

${ }^{\mathrm{c}}$ Centro de Investigação em Antropologia e Saúde, Department of Life Sciences, University of Coimbra, Coimbra, Portugal

${ }^{\mathrm{d}}$ Department of Life Sciences, University of Coimbra, Coimbra, Portugal

Running title: Periapical lesions in intentionally modified teeth

Key words: Dental modifications, periapical cyst, granuloma, dental infection, African slaves, $15^{\text {th }}$ $17^{\text {th }}$ centuries.

*Correspondence to:

Sofia N. Wasterlain

Departamento de Ciências da Vida, Calçada Martim de Freitas, 3000-456 Coimbra, Portugal

Telephone: +351239854105 Fax: +351239854129

E-mail address: sofiawas@,antrop.uc.pt 


\begin{abstract}
Intentional dental modifications are alterations of teeth usually performed as a ritual for aesthetic or identity purposes. However, the execution of the technique is not exempt from risk, and can be related to a higher prevalence of dental pathology, more specifically through the exposure of the dental pulp and consequent periapical inflammation. With the aim of analysing the relationship between intentional dental modifications and periapical inflammation, the current study evaluated 81 skeletons (49 females, 19 males, and 13 individuals of unknown sex) of enslaved Africans from Lagos, Portugal $\left(15^{\text {th }}-17^{\text {th }}\right.$ centuries $)$, of which $50(61.7 \%)$ had intentionally modified teeth. In all, 2285 sockets and 2063 teeth were observed. Two hundred and three intentionally modified anterior teeth $(27.2 \%)$ were identified. The differential diagnosis of periapical lesions was made following Dias and Tayles (1997), Dias et al. (2007), and Hillson (2001). Twenty five individuals (30.9\%) and 54 teeth (25 anterior and 29 posterior) showed macroscopic evidences of periapical lesions. In the anterior dentition, intentional modification was identified as the probable aetiology of 17 (68.0\%) periapical lesions, mostly granulomata or cysts, but also abscesses. The association between intentional modifications of the dentition and the presence of periapical lesions was found in both the maxilla and mandible. These results suggest that this cultural practice can predispose teeth to periapical inflammation, which may cause pain and sensitivity to cold, heat, and pressure, and probably had a negative impact on the quality of life of these individuals.
\end{abstract}

Key words: Dental modifications, periapical cyst, granuloma, dental infection, African slaves, $15^{\text {th }}$ $17^{\text {th }}$ centuries. 


\section{Introduction}

Excavations performed in 2009 at the Valle da Gafaria site, located outside the medieval walls of Lagos, in southern Portugal, revealed an urban discard deposit dated from the $15^{\text {th }}-17^{\text {th }}$ centuries. Among discarded objects and food residues, several human remains were found. In all, 158 individuals were exhumed, including males and females, adults and sub-adults, many of them aged less than 30 years (for more details about this archaeological assemblage see Wasterlain et al., 2015).

Morphometric analysis of the skulls led us to attribute an African origin to these individuals (Coelho, 2012), later confirmed by DNA analysis performed in two individuals (number 125 and number 166) recovered in the discard deposit burials from Valle da Gafaria (Martiniano et al., 2014). An AMS C14 date obtained for one individual resulted in 450 +/- 40 BP, Cal AD 14201480, Cal BP 540-470, Beta - 276508, which is compatible with the first historical reports of caravels arriving at Lagos with enslaved Africans (Tinhorão, 1997; Henriques, 2009). All the findings suggest that these bodies were probably African slaves of the period just prior to the transatlantic slave trade, who arrived at Lagos harbour and were discarded in the urban deposit after death (for more details, see Wasterlain et al., 2015).

Several of the individuals exhumed from Valle da Gafaria presented dental alterations, not attributed to accidental trauma, functional wear, or post-mortem fracture. Wasterlain et al. (2015) performed an exhaustive investigation on such alterations and concluded that all modifications were consistent with intentional filing of the mesial and/or distal borders of both incisors and canines. Intentional dental modifications (IDM) have been recorded in many different cultures and time periods (Almeida, 1953; Santos, 1962; Dias and Dias, 1964; Pindborg, 1969; Redinha, 1974; Inoue et al., 1995; Finucane et al., 2008; Reichart et al., 2008, among others). This cultural practice may be related to rites of passage, differential status, group identification, mourning, or embellishment (Milner and Larsen, 1991; Finucane et al., 2008; Barnes, 2010). 
In Wasterlain et al. (2015), 55.8\% of the 113 analysed individuals presented dental modifications on their anterior dentition, with $42.9 \%$ exhibiting modifications on both upper and lower teeth. The most frequently modified teeth were the incisors, followed by the canines. Dental intentional modifications were observed in both sexes and all age-groups. Despite the impossibility to infer a specific provenance for these slaves or the motivation/function behind this cultural practice, Wasterlain et al. (2015) concluded that the observed patterns of dental modifications were consistent with sub-Saharan African practices.

From a clinical point of view these dental changes can be quite harmful, compromising both the tooth and the support structures. Several possible consequences have been described, such as the injury of the apical neurovascular bundle, pulp necrosis (caused by the exposure of the pulp to a broad spectrum of micro-organisms, higher caries incidence in the modified surface, or thermal aggression to the exposed dentin), loss of masticatory function, dental enamel hypoplasia in the permanent teeth, post-avulsion lock-jaw, alveolar-dental fracture, and apical and/or root fractures (Martins and Martins, 1986). In very young individuals in whom the apex closure has not been completed, such modifications may lead to dental necrosis and subsequently abscess formation, ultimately resulting in the tooth loss (Roseiro, 2013).

Although there are several publications describing IDM in present-day and past populations, almost none discusses the complications post-modification procedures. There are a few exceptions though. For example, in a sample of intentionally modified teeth recovered in two Brazilian cemeteries (cemetery of Pretos Novos in Rio de Janeiro and Sé church of Salvador, Bahia), Liryo et al. (2011) found a low frequency of association between intentional dental modifications and periapical cavities. Recent anthropological and ethnographic studies in modern populations of Mozambique who still perform these rituals have shown a possible association with a higher risk of dental pathology, like caries and infections (Roseiro, 2013).

The aim of this study is to present an additional image of the quality of life of these individuals. This will enrich the scanty osteoarchaeological and paleopathological documentation 
on the enslaved people that arrived Portugal between the $15^{\text {th }}$ and the $17^{\text {th }}$ centuries, adding to the few descriptions available for the relationship between intentional dental modifications and periapical inflammation. On the other hand, it is believed that data presented in this study are not only of anthropological relevance but also of clinical importance, since intentional dental modification is a cultural practice still performed amongst several African ethnic groups.

\section{Material and Methods}

For this study a sample of the Valle da Gafaria's collection (Lagos, Portugal) analysed by Wasterlain et al. (2015) was selected, in order to include only individuals aged more than 12 years old with at least four observable teeth $(\mathrm{N}=81)$. The age-at-death was estimated on the basis of the epiphyseal fusion of the femoral head (Ferembach et al., 1980), third molar eruption (Ozle et al., 2007), spheno-occipital syncondrosis fusion (Shirley and Jantz, 2011), morphologic changes in the pubic symphysis (Brooks and Suchey, 1990), and auricular surface of the ilium (Lovejoy et al., 1985). Sexual diagnosis was made through the metric and morphological analysis of the skull and innominate (Ferembach et al., 1980; Uytterschaut, 1986; Buikstra and Ubelaker, 1994; Bruzek, 2002; Murail et al., 2005).

Initially, teeth were examined for presence, post- and ante-mortem loss, and eruption problems (partial eruption, anomalous eruption, or no eruption as a result of young age, impaction or agenesis). All fully erupted teeth were examined under good lighting conditions by careful visual inspection (Hillson, 2001) for the presence of intentional dental modifications (IDM). Special care was taken to exclude unintentional modifications as ante-mortem or post-mortem fractures, dental caries, and masticatory or occupational wear (for more details see Wasterlain et al., 2015).

Cavities in the bone around the apical foramen at the apex of the roots (or around a lateral foramen at the site of a root) were macroscopically inspected, and their location recorded. A total of 43 periapical digital x-rays were performed (RVG- Radiovisiography System, Trophy x-ray unit; voltage: $70 \mathrm{kV}$; mean time exposure: $0.125 \mathrm{~s}$ ). As radiographic analysis of all maxilla/mandible was 
not performed, whenever possible teeth were removed from their sockets in order to expose hidden periapical cavities (those without opening). The differential diagnoses of periapical lesions were made following Dias and Tayles (1997), Dias et al. (2007), and Hillson (2001), taking into account the appearance of the wall of the cavity, the lesion radius (measured in mm with a graduated probe), and the nature of the opening (special care was taken to distinguish sinus from openings made or enlarged by post-mortem damage). Although Dias and Tayles (1997) have defined a periapical granuloma as a cavity with a radius smaller than $3 \mathrm{~mm}$ with smooth walls, and a radicular cyst as a larger cavity of the same type, Hillson (2001) warned that it is possible for a granuloma to be larger and a cyst smaller, admonishing the use of the size of the lesion as a distinctive factor between granulomata and cysts. Therefore, in this paper, all cavities with smooth walls and circumscribed margins were indistinctively registered as granulomata/cyst. Cavities with roughened walls, ragged margins and/or a bony sinus leading to the subperiosteal surface were identified as abscesses (Dias and Tayles, 1997). The probable aetiology (dental caries, dental wear, trauma, intentional dental modification) of the lesions was also recorded.

The statistical significance of the recorded values was tested with independent samples chisquare. Statistical analysis was conducted by using the IBM SPSS statistics ${ }^{\circledR}$ program (version 22.0).

\section{Results}

\section{Individuals' biological profile}

The biological profile of the individuals selected for the present study can be observed in Table S1. Of the 81 individuals under analysis, 49 (60.5\%) were classified as females, 19 (23.5\%) as males, and in $13(16.0 \%)$ it was not possible to estimate sex. Age-at-death ranges between 12 years and 50 years. In nine cases, the poor state of preservation and/or incompleteness of the skeletons made it impossible to estimate age-at-death but in each case it was confirmed that these individuals were older than 12 years at time of death. An African ancestry could be confirmed in the 
63 individuals for whom this kind of analysis could be performed (Coelho, 2012; Navega et al., 2015). In the selected sample, 50 individuals $(61.7 \%)$ had intentionally modified teeth.

\section{Teeth sample}

In all, 2285 sockets and 2063 permanent fully erupted teeth (757 anterior and 1306 posterior; 1027 upper and 1036 lower) were analysed (Table 1). It should be noted, however, that 51 of these tooth sockets were damaged post-mortem impairing their evaluation. Of the observable sockets, the exact same number of teeth $(\mathrm{N}=96,4.2 \%)$ were lost post-mortem and before death. Eruption problems (partial eruption, anomalous eruption or complete failure to erupt as a result of young age, impaction or agenesis) were observed in 30 tooth positions (1.3\%).

\section{Intentional Dental Modifications}

Both women (61.2\%) and men (63.2\%) presented IDM. No differences were found between the two sexes (Chi-square $=3.471 ; \mathrm{df}=4 ; \mathrm{P}<0.482)$. Only anterior teeth were culturally modified. Of the 757 anterior fully erupted teeth, ten could not be evaluated for the presence of IDM due to gross carious lesions or severe dental wear. Of the 747 anterior teeth (361 upper and 386 lower) analysed, 203 (27.2\%) were modified. Anterior upper teeth were more modified (39.6\%) than lower ones $(15.5 \%)($ Chi-square $=54.602, \mathrm{df}=1, \mathrm{P}<0.000)$.

\section{Periapical lesions}

In Table 2, the number and type of periapical lesions, their location, and the different ways in which the area of bone loss has been exposed to view, or otherwise detected, are presented. Twenty five (30.9\%) of the 81 individuals presented macroscopic cavities in the alveolar bone compatible with periapical inflammation. In all, 54 periapical lesions were found. The majority of these individuals $(\mathrm{N}=17)$ registered only one or two lesions; however, one individual (no. 136) exhibited five lesions. 
Most osteolytic lesions (77.8\%) were consistent with a diagnosis of granuloma or cyst. Seven $(13.0 \%)$ were diagnosed as periapical abscesses, and only five $(9.3 \%)$ were considered residual lesions as they were remodelling due to the loss of the corresponding tooth. None of the cavities had roughened, ragged margins, involving a large irregular area, which could suggest osteomyelitis. Besides, no necrotic bone with an involucrum or multiple sinuses draining to the surface were found.

Most lesions (79.6\%) were visible on the buccal/labial plate of the alveolar process. None could be observed only on the lingual plate. Four cavities (7.4\%) showed an opening to both cortical plates of the alveolar process, and one lesion on the maxilla appeared to have communication with the maxillary sinus. In six cases the periapical lesions had no opening in the cortical bone, and could only be observed after the removal of the tooth from its socket.

Females were relatively more susceptible to this condition ( $40.8 \%$ affected) than males (26.3\%). However this difference was not significant (Chi-square test: 1.238; d.f. $=2 ; \mathrm{p}=0.266$ ). No periapical cavities were found in those individuals whose sex could not be estimated.

Although upper teeth were slightly more affected by periapical lesions (3.1\%) than the lower ones $(2.1 \%)$, no significant differences were found between the maxilla and the mandible (Chisquare test: 2.109 ; d.f. $=1 ; \mathrm{p}=0.146)$. Similarly, anterior teeth $(3.2 \%)$ were not significantly more affected by periapical lesions than posterior teeth (2.2\%) (Chi-square test: 1.888 ; d.f. $=1 ; \mathrm{p}=0.169)$.

Concerning the aetiology of the periapical lesions (Table 3), 24 (44.4\%) were related to decayed teeth and 17 (31.5\%) were associated with modified teeth. This can be observed in Figure 1, which provides an anterior view of the maxilla of the individual no. 120 with all upper incisors intentionally modified and periapical lesions related to both upper central incisors. In the corresponding X-ray (Figure 2) there are oval radiolucent areas related to the apices of the modified teeth. In 11 lesions it was not possible to infer the aetiology due to ante-mortem $(\mathrm{N}=6)$ or postmortem tooth loss $(\mathrm{N}=5)$. In two other cases, the teeth were present without apparent pulp involvement. In these 13 lesions the aetiology was recorded as unknown. 
The possible aetiology of the periapical lesions was distinct for anterior teeth and posterior teeth. From the 29 lesions located in the posterior dentition, $75.9 \%$ were related to dental caries whereas $68.0 \%$ of the 25 anterior teeth with periapical lesions were intentionally modified.

The most affected teeth were the central incisors (29.6\% of total lesions) and the first molars (24.1\% of total lesions): the majority of the central incisors $(81.3 \%)$ were intentionally modified whereas most first molars $(53.8 \%)$ were decayed.

Since this study aims to investigate the relationship between intentional dental modifications and periapical lesions, and such cultural practice was exclusively observed in the anterior dentition of the Lagos's individuals, it is crucial to analyse only the anterior dentition in order to understand if the modified teeth were more prone to periapical lesions. In fact, it was confirmed that anterior modified teeth were significantly more affected by periapical lesions $(9.3 \%)$ than unmodified teeth $(0.4 \%)$ (Chi-square test: $39.466 ;$ d.f. $=1 ; \mathrm{p}<0.000)$. The association between intentional modifications of the dentition and the presence of periapical lesions was found in both the maxilla (Chi-square test: $11.405 ;$ d.f. $=1 ; \mathrm{p}=0.001$ ) and mandible (Chi-square test: 32.912 ; d.f. $=1 ; \mathrm{p}<$ $0.000)$.

In the present sample, most modified teeth $(139 ; 76.4 \%)$ presented removal of both mesial and distal incisal angles. Thirty-three teeth (18.1\%) had only the mesial edge removed, and 10 (5.5\%) showed only the distal angle modified. However, no association was found between the presence of periapical lesions and the pattern of dental modification (Chi-square test: 1.795; d.f. $=2$; $\mathrm{p}=0.408)$

\section{Discussion}

Given that an important archaeological assemblage of African individuals recovered from Lagos (Portugal), who lived between the $15^{\text {th }}$ and $17^{\text {th }}$ centuries, had intentional dental modifications, it was important to assess the relationship between this cultural practice and periapical inflammation to better understand the impact of such lesions on the quality of their lives. 
In this investigation only those aged more than 12 years old and with at least four observable teeth were selected. Therefore, the sample analysed in the present study comprises 81 individuals of the 158 found in Valle da Gafaria, Lagos, Portugal. Intentional dental modifications were almost equally recorded in women and men, and the anterior upper teeth were significantly more modified than the anterior lower. The same trend was observed by Wasterlain et al. (2015) with the entire collection.

Concerning periapical inflammation, a relatively high percentage of the analysed individuals $(30.9 \%, \mathrm{n}=25)$ presented macroscopic cavities in the alveolar bone compatible with periapical inflammation. In many instances, the periapical lesions were related to decayed teeth $(44.4 \%)$, but in a considerable number of cases they were associated with modified teeth $(31.5 \%)$. More interestingly, when this pathological condition was exclusively observed in the anterior dentition of the Lagos's individuals, it was confirmed that anterior modified teeth were significantly more affected by periapical lesions $(9.3 \%)$ than unmodified teeth $(0.4 \%)$. Moreover, it was noted that periapical lesions predominantly affected intentionally modified teeth regardless of the number of dental angles removed.

In a sample from the cemetery of Pretos Novos, Rio de Janeiro (Brazil), only a periapical abscess was found associated with the modified teeth. Furthermore, in a sample from the Sé church, Bahia (Brazil), just $1.5 \%$ of the loci showed apical cavities. It should be highlighted, however, that in both Brazilian samples, the two conditions (IDM and periapical lesions) could just be observed concomitantly in a relatively low number of cases because many teeth were loose (Liryo et al., 2011). In other words, it is possible that many of the modified teeth were associated with periapical lesions but as the corresponding jaws are absent makes it is impossible to retrieve that information.

In contrast, in 2008, Reichart et al. examined IDM in 33 skulls from the Berlin Museum of Medical History, which were collected in Cameron around the turn of the $20^{\text {th }}$ century. In this sample, pulp exposure was observed in $30.3 \%$ of the modified teeth whereas periapical osteitis or 
radicular cysts were found in $27.3 \%$ of the cases. As in the present study, all lesions were located overlying the apex of the modified anterior teeth.

Similarly, in a Mesoamerican pre-Hispanic sample, a positive relationship between periapical inflammation and IDM was found (Amado, 1995; Olvera et al., 2010). In this case, the teeth were drilled with inlays and it was suggested that the high temperatures originated by friction had been a causative factor of the periapical inflammation. As already mentioned, in the Lagos's sample there is no evidence of such practice, nor staining, or ablation. All modifications are consistent with filing (for more details, see Wasterlain et al., 2015). This specific practice may be also quite harmful, by exposing the pulp to a broad spectrum of micro-organisms and therefore leading to the pulp necrosis, or other consequences (Goose, 1963; Martins and Martins, 1986).

In an ethnographic study conducted in Angola several decades ago, Almeida (1937) noted that immediately after a dental modification procedure of filing, there would be only slight pain and minor bleeding. However, he reported dental caries, gingivitis, pyorrhoea, and jaw lesions as common long-term consequences. Nevertheless, it has also been suggested that many teeth suffering violent trauma (accidental or wilful, such as dental modification) may not develop periapical abscesses due to defence mechanisms, namely deposition of secondary dentine, which limits the exposure of the pulp and the consequent periapical infection (Goose, 1963; Dias and Tayles, 1997; Hillson, 2001, 2008; Roseiro, 2013). In the present sample, there were cases where this could have happened. For example, Figure 3 shows the right upper central incisor of individual no. 44, with the mesial incisal angle removed. This tooth was not associated with any periapical lesions. However, the analysis of the periapical x-ray image (Figure 4) showed an alteration of the dental pulp morphology on the mesial pulp horn. This was probably due to the deposition of irregular secondary dentine in response to the aggression, leading to the modification of the normal contour of the pulp chamber, the pulp remaining vital. A similar description was made by Goose (1963) for one modified tooth from West Africa. 
In 2007, Fabian and Mumghamba conducted a study among living adults from South East Tanzania in order to determine the relationship between tooth and lip mutilations (piercing the upper lip and inserting a wooden stick) and the prevalence of tooth loss and the associated oral mucosal lesions, respectively. Concerning dental modifications, they concluded that this practice did not lead to significant tooth loss. In the present study, it was not possible to perform such investigation since it is impracticable to discern between the several possible causes of ante-mortem tooth loss in skeletal material.

Periapical lesions start to develop close to the tooth root in the middle of the maxilla/mandible and expand to the outer border of the bone. Depending on the severity of the inflammatory process, the bone defect caused by odontogenic infection does not necessarily have to be visible on the outer border of the maxilla/mandible (Dias and Tayles, 1997). That is the reason why radiographic methods have been considered the most accurate way of determining the prevalence of periapical lesions. In the anthropological literature it is commonly stated that if x-rays are not used in dry skulls, false low prevalence rates can be established (Hillson, 2001, 2005). In fact, in six cases of the present study the periapical lesions had no opening in the cortical bone, and could only be observed after the removal of the tooth from its socket. Besides, periapical lesions were more frequently visible on the buccal/labial plate of the alveolar process (79.6\%), particularly of the anterior dentition. This is probably due the higher density of the lingual cortical bone in this section. Considering that radiological analysis of all individuals/teeth was not performed, the frequency of periapical inflammation in the Lagos's individuals could be somewhat higher than that presented here.

Most periapical lesions observed in the present sample were cavities with smooth walls and circumscribed margins, being therefore diagnosed as possible granulomata or cysts $(77.8 \%)$. A lower percentage $(13.0 \%)$ of cavities had roughened walls, ragged margins and/or a bony sinus leading to the subperiosteal surface, being identified as dental abscesses. This result is in 
accordance with the expected. Dias and Tayles (1997) highlighted that most periapical cavities would be occupied by relatively benign lesions such as granulomata and apical periodontal cysts.

In the pre-antibiotic era, odontogenic infections could be very serious conditions that were often life-threatening (Dias and Tayles, 1997). It is possible that the low frequency of dental abscesses and complete absence of osteomyelitis in the Lagos's sample are due to the non-survival of those individuals who developed these more serious conditions. In fact, both acute abscesses and osteomyelitis will not result in bony changes because there is not enough time for the stimulation of osteoclastic resorption (Dias and Tayles, 1997; Hillson, 2001). If the host immune response is inadequate or if the virulence of the infecting agent is high, other potentially lethal complications may occur from an untreated abscess, namely cellulitis, systemic bacteraemia, and ultimately generalized septicaemia (Dias and Tayles, 1997). In opposition to the abscess, which is characterized by localized severe pain, tooth extrusion, together with systemic effects (e.g., fever, enlarged and tender lymph nodes, and general malaise), both periapical granulomata and apical cysts are relatively asymptomatic. Although there may be some minor symptoms such as slight pain during masticatory activities, there are no systemic consequences (Dias and Tayles, 1997; Hillson, 2001). While recognizing that many of these injuries, especially in its chronic phase, have no symptoms, it is believed that several may have affected the morbidity of these individuals in some way. Finally, in five cases $(9.3 \%)$ the lesions were classified as residual. As already described by other authors (Dias and Tayles, 1997; Ortner, 2003; Dias et al. 2007), periapical lesions may be observed without an apparent causative source of infection. In such cases, the septic tooth had exfoliated (or was extracted due to associated pain), and the socket has remodelled.

\section{Conclusion}

It is believed that the individuals recovered in the Valle da Gafaria, Lagos $\left(15^{\text {th }}-17^{\text {th }}\right.$ centuries), were enslaved, captured somewhere in sub-Saharan Africa, bought and shipped by the Portuguese from multiple locations, and brought to the harbour of Lagos (Fonseca, 2010; Caldeira, 
2013). It is not known exactly how many slaves were transported on each ship. A vessel of 60 tons could carry a maximum of 220-255 slaves, between adults and children. It is known, however, that the ships' capacity was often largely superseded (Caldeira, 2013). The slaves were frequently tied and accommodated in overcrowded spaces with insufficient ventilation. Moreover, the several weeks of journey (the exact duration is unknown) were characterized by scarcity of water and food (Smallwood, 2008; Caldeira, 2013). Those who did not die during the journey - and the historical sources refer to values sometimes exceeding 39\% (Mendes, 2004) - arrived extremely debilitated. The Lagos's sample provides a great opportunity to learn more about the relationship between intentional dental modifications and periapical inflammation in these captive individuals. Not only are there few studies that analyse this relationship but Lagos has the largest osteological sample in the World that allows for this research. Despite the impossibility of performing systematic radiological analyses of all individuals/teeth, the results here presented suggest that the cultural practice of intentional dental modification can predispose teeth to periapical inflammation, which may cause pain and sensitivity to cold, heat and pressure. These symptoms probably had a negative impact on the quality of life of the enslaved individuals exhumed from a deposit of urban waste of the Valle da Gafaria. Besides the difficult journey in sub-human conditions, these individuals would have had tooth sensitivity and/or pain, which would hinder a normal mastication. In cases of abscesses, the systemic effects, such as persistent fever, enlarged regional lymph nodes, and general malaise, would further affect the quality of life of these individuals and could even lead to the development of fatal conditions.

\section{Acknowledgments}

The authors thank Centro de Investigação em Antropologia e Saúde, Centro de Ecologia Funcional, Dryas Arqueologia Lda., Styx, Estudos de Antropologia Lda., and Catarina Coelho. The co-author Maria Teresa Ferreira was financed by Gerda Henkel Foundation. The co-author Sofia N. Wasterlain was financed by national funds by FCT - Fundação para a Ciência e Tecnologia, under 
the project with the reference UID/ANT/00283/2013. The authors also acknowledge the anonymous reviewers whose valuable comments and suggestions allowed us to improve the manuscript.

The authors state that they do not have any conflict of interest to declare.

\section{Supporting Information}

Supporting tables: Table S1.

Table S1. Biological profile of the selected individuals exhumed from the deposit of urban waste in Valle da Gafaria (Lagos, Portugal).

\section{References}

Almeida A. 1937. Sôbre mutilações étnicas dos aborígenes de Angola. Oficinas Gráficas: Lisboa. Almeida R. 1953. Mutilações dentárias nos Negros da Lunda. Anais do Instituto de Medicina Tropical 10: 3602-3639.

Amado GM. 1995. Actualización sobre los conceptos de odontologia prehispánica en Mesoamérica In VIII Simposio de Investigaciones Arqueológicas en Guatemala, Laporte JP, Escobedo H (eds.). Museo Nacional de Arqueología y Etnología: Guatemala; 129-144.

Barnes DM. 2010. Dental Modification: An Anthropological Perspective. University of Tennessee Honors Thesis Project. http://trace.tennessee.edu/utk_chanhonoproj/1345

Brooks S, Suchey JM. 1990. Skeletal age determination based on the os pubis: A comparison of the Acsádi-Nemeskéri and Suchey-Brooks methods. Journal of Human Evolution 5: 227-238.

Bruzek J. 2002. A method for visual determination of sex, using the human hip bone. American Journal of Physical Anthropology 117: 157-168.

Buikstra J, Ubelaker D. 1994. Standards for data collection from human skeletal remains. Arkansas Archaeological Survey Research Series; 44. Arkansas Archeological Survey: Fayetteville, AR. 
Caldeira AM. 2013. Escravos e traficantes no Império Português: o comércio negreiro português no Atlântico durante os séculos XV a XIX. A Esfera dos Livros: Lisboa.

Coelho C. 2012. Uma identidade perdida no mar e reencontrada nos ossos: avaliação das afinidades populacionais de uma amostra de escravos dos séculos XV-XVI. Masters Dissertation on Human Evolution and Biology. University of Coimbra: Coimbra.

Dias J, Dias M. 1964. Os Macondes de Moçambique. Junta de Investigações do Ultramar: Lisboa.

Dias G, Tayles N. 1997. ‘Abscess cavity’ - a misnomer. International Journal of Osteoarchaeology 7: 548-554.

Dias GJ, Prasad K, Santos AL. 2007. Pathogenesis of apical periodontal cysts: guidelines for diagnosis in paleopathology. International Journal of Osteoarchaeology 17: 619-626.

Fabian FM, Mumghamba EGS. 2007. Tooth and lip mutilation practices and associated tooth loss and oral mucosal lesions in the Makonde people of Southeast Tanzania. East African Medical Journal 84: 183-187.

Ferembach D, Schwidetzky I, Stloukal M. 1980. Recommendations for age and sex diagnosis of skeletons. Journal of Human Evolution 9: 517-550.

Finucane BC, Manning K, Touré M. 2008. Prehistoric dental modification in West Africa - Early evidence from Karkarichinkat Nord, Mali. International Journal of Osteoarchaeology 18: $632-640$.

Fonseca J. 2010. Escravos e Senhores na Lisboa quinhentista. Edições Colibri: Lisboa.

Goose DH. 1963. Tooth-mutilation in West Africans. Man 63: 91-93.

Henriques IC. 2009. A Herança Africana em Portugal. CTT, Correios de Portugal: Lisboa.

Hillson S. 2001. Recording dental caries in archaeological human remains. International Journal of Osteoarchaeology 11: 249-289.

Hillson S. 2005. Teeth, $2^{\text {nd }}$ ed. Cambridge University Press: Cambridge.

Hillson S. 2008. Dental Pathology. In Biological anthropology of the human skeleton (2 ${ }^{\text {nd }}$ ed.), Katzenberg MA, Saunders SR (eds.). Wiley-Liss: New Jersey; 301-333. 
Inoue N, Sakashita R, Inoue M, Kamegai T, Ohashi K, Katsivo M. 1995. Ritual ablation of front teeth in modern and recent Kenyans. Anthropological Science 103: 263-277.

Liryo A, Souza SM, Cook DC. 2011. Dentes intencionalmente modificados e etnicidade em cemitérios do Brasil Colônia e Império. Revista do Museu de Arqueologia e Etnologia 21: $315-334$.

Lovejoy C, Meindl R, Pryzbeck T, Mensforth R. 1985. Chronological metamorphosis of the auricular surface of the ilium: a new method for the determination of adult skeletal age at death. American Journal of Physical Anthropology 68: 15-28.

Martiniano R, Coelho C, Ferreira MT, Neves MJ, Pinhasi R, Bradley DG. 2014. Genetic Evidence of African Slavery at the Beginning of the Trans-Atlantic Slave Trade. Scientific Reports 4, 5994. DOI: $10.1038 /$ srep05994

Martins MAD, Martins MRAR. 1986. A arte dentária de carácter étnico (a propósito de mutilações dento-maxilares intencionais). Revista Portuguesa de Estomatologia e Cirurgia MaxiloFacial 27: 519-531.

Mendes AA. 2004. Portugal e o tráfico de escravos na primeira metade do século XVI. Africana Studia 7: 13-30.

Milner GR, Larsen CS. 1991. Teeth as Artifacts of Human Behavior: Intentional Mutilation and Accidental modification. In Advances in Dental Anthropology, Kelley MA, Larsen CS (ed.). Wiley-Liss: New York; 357-378.

Murail P, Bruzek J, Houët F, Cunha E. 2005. DSP: a tool for probabilistic sex diagnosis using worldwide variability in hip-bone measurements. Bulletins et Mémoires de la Société d'Anthropologie de Paris 17: 167-176.

Navega D, Coelho C, Vicente R, Ferreira MT, Wasterlain S, Cunha E. 2015. AncesTrees: ancestry estimation with randomized decision trees. International Journal of Legal Medicine 129: $1145-1153$. 
Olvera SD, Garcia LO, Hernández JF, Sánchez RO, Torres CL, López JCJ. 2010. Decorados dentales prehispánicos. Revista Odontológica Mexicana 14: 99-106.

Olze A, Van Niekerk P, Schulz R, Schmeling A. 2007. Studies of the chronological course of wisdom tooth eruption in a black African population. Journal of Forensic Sciences $\mathbf{5 2}$ : $1161-1163$

Ortner DJ. 2003. Identification of pathological conditions in human skeletal remains. Academic Press: San Diego.

Pindborg JJ. 1969. Dental mutilation and associated abnormalities in Uganda. American Journal of Physical Anthropology 31: 383-389.

Redinha J. 1974. Etnias e culturas de Angola. Instituto de Investigação Científica de Angola: Luanda.

Reichart P, Creutz U, Scheifele C. 2008. Dental mutilations and associated alveolar bone pathology in African skulls of the anthropological skull collection, Charite, Berlin. Journal of Oral Pathology \& Medicine 37: 50-55.

Roseiro AHR. 2013. Símbolos e Práticas Culturais dos Makonde. PhD Thesis in Social and Cultural Anthropology. University of Coimbra: Coimbra.

Santos JN. 1962. Mutilações dentárias em pretos de Moçambique. Garcia de Orta 10: 263-282.

Shirley NR, Jantz RL. 2011. Spheno-occipital synchondrosis fusion in modern Americans. Journal of Forensic Sciences 56: 580-585.

Smalwood SE. 2008. Saltwater Slavery: A middle passage from Africa to American diaspora. Harvard University Press: Harvard.

Tinhorão JR. 1997. Os Negros em Portugal: uma presença silenciosa, $2^{\text {nd }}$ ed. Editorial Caminho: Lisboa.

Uytterschaut HT. 1986. Sexual dimorphism in human skulls a comparison of sexual dimorphism in different populations. Journal of Human Evolution 1: 243-250. 
Wasterlain SN, Neves MJ, Ferreira MT. 2015. Dental modifications in a skeletal sample of enslaved Africans found at Lagos (Portugal). International Journal of Osteoarchaeology. DOI:

10.1002/oa.2453 
Table 1. Teeth present, missing ante-mortem, lost post-mortem, and with eruption related problems in each tooth type.

\begin{tabular}{|c|c|c|c|c|c|c|c|c|c|}
\hline \multirow[t]{2}{*}{ Tooth type } & \multicolumn{2}{|c|}{ Present } & \multicolumn{2}{|c|}{ Lost AM } & \multicolumn{2}{|c|}{ Lost PM } & \multicolumn{2}{|c|}{ ERP } & \multirow{2}{*}{$\frac{\text { Total }}{n}$} \\
\hline & $\mathrm{n}$ & $\%$ & $\mathrm{n}$ & $\%$ & $\mathrm{n}$ & $\%$ & $\mathrm{n}$ & $\%$ & \\
\hline Central incisor & 231 & 81.6 & 15 & 5.3 & 37 & 13.1 & 0 & 0 & 283 \\
\hline Lateral incisor & 257 & 90.5 & 4 & 1.4 & 22 & 7.7 & 1 & 0.4 & 284 \\
\hline Canine & 269 & 94.4 & 2 & 0.7 & 13 & 4.6 & 1 & 0.4 & 285 \\
\hline First premolar & 273 & 95.1 & 7 & 2.4 & 7 & 2.4 & 0 & 0 & 287 \\
\hline Second premolar & 275 & 95.2 & 9 & 3.1 & 2 & 0.7 & 3 & 1.0 & 289 \\
\hline First molar & 253 & 88.5 & 28 & 9.8 & 5 & 1.7 & 0 & 0 & 286 \\
\hline Second molar & 261 & 90.6 & 23 & 8.0 & 4 & 1.4 & 0 & 0 & 288 \\
\hline Third molar & 244 & 86.2 & 8 & 2.9 & 6 & 2.1 & 25 & 8.8 & 283 \\
\hline Total & 2063 & 90.3 & 96 & 4.2 & 96 & 4.2 & 30 & 1.3 & 2285 \\
\hline $\begin{array}{l}\text { Lost AM - Lost a } \\
\text { Lost PM - Lost } p \\
\text { ERP - Eruption } r\end{array}$ & 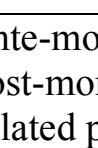 & & & & & & & & \\
\hline
\end{tabular}


Table 2. Number and type of periapical lesions, location and the different ways in which the area of bone loss has been exposed to view, or otherwise detected in the selected individuals exhumed from the deposit of urban waste in Valle da Gafaria (Lagos, Portugal).

\begin{tabular}{|c|c|c|c|c|}
\hline Individual no. & Number of lesions & Tooth $^{*}$ & Type of lesion ${ }^{\mathrm{T}}$ & Area of bone loss \\
\hline 32 & 1 & 11 & $\mathrm{G} / \mathrm{C}$ & Buccal \\
\hline \multirow[t]{4}{*}{38} & 4 & 16 & $\mathrm{~A}$ & Buccal and Lingual \\
\hline & & 26 & $\mathrm{~A}$ & Buccal \\
\hline & & 42 & A & Buccal \\
\hline & & 46 & $\mathrm{G} / \mathrm{C}$ & Buccal \\
\hline \multirow[t]{4}{*}{39} & 4 & 11 & $\mathrm{G} / \mathrm{C}$ & Buccal \\
\hline & & 16 & $\mathrm{G} / \mathrm{C}$ & Buccal \\
\hline & & 22 & $\mathrm{G} / \mathrm{C}$ & Buccal and Lingual \\
\hline & & 46 & $\mathrm{R}$ & Buccal \\
\hline \multirow[t]{2}{*}{44} & 2 & 25 & $\mathrm{G} / \mathrm{C}$ & Buccal and Lingual \\
\hline & & 36 & $\mathrm{R}$ & Buccal \\
\hline \multirow{3}{*}{60} & & & & Sinus \\
\hline & 2 & 26 & $\mathrm{~A}$ & \\
\hline & & 36 & $\mathrm{G} / \mathrm{C}$ & Buccal \\
\hline 69 & 1 & 21 & $\mathrm{G} / \mathrm{C}$ & Buccal and Lingual \\
\hline \multirow[t]{4}{*}{75} & 4 & 26 & $\mathrm{R}$ & Buccal \\
\hline & & 35 & A & Buccal \\
\hline & & 36 & $\mathrm{G} / \mathrm{C}$ & Buccal \\
\hline & & 47 & $\mathrm{G} / \mathrm{C}$ & Buccal \\
\hline 78 & 4 & 15 & $\mathrm{G} / \mathrm{C}$ & Buccal \\
\hline
\end{tabular}




\begin{tabular}{|c|c|c|c|c|}
\hline & & 18 & $\mathrm{G} / \mathrm{C}$ & Without opening \\
\hline & & 35 & $\mathrm{G} / \mathrm{C}$ & Buccal \\
\hline & & 45 & $\mathrm{G} / \mathrm{C}$ & Buccal \\
\hline \multirow[t]{2}{*}{79} & 2 & 18 & $\mathrm{G} / \mathrm{C}$ & Buccal \\
\hline & & 27 & $\mathrm{G} / \mathrm{C}$ & Without opening \\
\hline 82 & 1 & 22 & $\mathrm{G} / \mathrm{C}$ & Without opening \\
\hline 94 & 1 & 35 & $\mathrm{~A}$ & Without opening \\
\hline \multirow[t]{2}{*}{95} & 2 & 21 & $\mathrm{G} / \mathrm{C}$ & Buccal \\
\hline & & 31 & $\mathrm{G} / \mathrm{C}$ & Buccal \\
\hline 98 & 1 & 34 & $\mathrm{G} / \mathrm{C}$ & Buccal \\
\hline \multirow[t]{3}{*}{100} & 3 & 11 & $\mathrm{G} / \mathrm{C}$ & Buccal \\
\hline & & 21 & $\mathrm{G} / \mathrm{C}$ & Buccal \\
\hline & & 41 & $\mathrm{G} / \mathrm{C}$ & Buccal \\
\hline 107 & 1 & 21 & $\mathrm{G} / \mathrm{C}$ & Buccal \\
\hline \multirow[t]{2}{*}{120} & 2 & 11 & $\mathrm{G} / \mathrm{C}$ & Buccal \\
\hline & & 21 & $\mathrm{G} / \mathrm{C}$ & Buccal \\
\hline \multirow[t]{2}{*}{125} & 2 & 21 & $\mathrm{G} / \mathrm{C}$ & Buccal \\
\hline & & 22 & $\mathrm{G} / \mathrm{C}$ & Without opening \\
\hline 133 & 1 & 32 & $\mathrm{G} / \mathrm{C}$ & Buccal \\
\hline \multirow[t]{5}{*}{136} & 5 & 13 & $\mathrm{R}$ & Buccal \\
\hline & & 26 & $\mathrm{G} / \mathrm{C}$ & Buccal \\
\hline & & 33 & $\mathrm{G} / \mathrm{C}$ & Buccal \\
\hline & & 35 & $\mathrm{G} / \mathrm{C}$ & Buccal \\
\hline & & 44 & $\mathrm{G} / \mathrm{C}$ & Buccal \\
\hline 148 & 1 & 36 & $\mathrm{G} / \mathrm{C}$ & Buccal \\
\hline
\end{tabular}


1

2

3

4

5

6

7

8

9

10

11

12

13

14

15

16

17

18

19

20

21

22

23

24

25

26

27

28

29

30

31

32

33

34

35

36

37

38

39

40

41

42

43

44

45

46

47

48

49

50

51

52

53

54

55

56

57

58

59

60

\begin{tabular}{|c|c|c|c|c|}
\hline 150 & 2 & 11 & $\mathrm{G} / \mathrm{C}$ & Buccal \\
\hline & & 31 & $\mathrm{G} / \mathrm{C}$ & Without opening \\
\hline 151 & 1 & 44 & $\mathrm{G} / \mathrm{C}$ & Buccal \\
\hline \multirow[t]{3}{*}{157} & 3 & 22 & $\mathrm{G} / \mathrm{C}$ & Buccal \\
\hline & & 26 & $\mathrm{R}$ & Buccal \\
\hline & & 35 & A & Buccal \\
\hline \multirow[t]{3}{*}{160} & 3 & 21 & $\mathrm{G} / \mathrm{C}$ & Buccal \\
\hline & & 31 & $\mathrm{G} / \mathrm{C}$ & Buccal \\
\hline & & 42 & $\mathrm{G} / \mathrm{C}$ & Buccal \\
\hline 170 & 1 & 17 & $\mathrm{G} / \mathrm{C}$ & Buccal \\
\hline
\end{tabular}

Fédération Dentaire Internationale

${ }^{ } \mathrm{G} / \mathrm{C}$ - Granuloma/cyst; A - Abscess; R - Residual lesion; IDM - Intentional Dental Modification 
Table 3. Possible etiology of the periapical lesions, by tooth type, in the selected individuals exhumed from the deposit of urban waste in Valle da Gafaria (Lagos, Portugal).

\begin{tabular}{|c|c|c|c|c|c|c|c|}
\hline \multirow{2}{*}{ Tooth type } & \multicolumn{2}{|c|}{ Caries } & \multicolumn{2}{|c|}{ Dental Modification } & \multicolumn{2}{|c|}{ Unknown } & \multirow{2}{*}{ Total } \\
\hline & $\mathrm{n}$ & $\%$ & $\mathrm{n}$ & $\%$ & $\mathrm{n}$ & $\%$ & \\
\hline Central incisor & 1 & 6.2 & 13 & 81.3 & 2 & 12.5 & 16 \\
\hline Lateral incisor & 0 & 0.0 & 4 & 57.1 & 3 & 42.9 & 7 \\
\hline Canine & 1 & 50.0 & 0 & 0.0 & 1 & 50.0 & 2 \\
\hline First premolar & 3 & 100.0 & 0 & 0.0 & 0 & 0.0 & 3 \\
\hline Second premolar & 8 & 100.0 & 0 & 0.0 & 0 & 0.0 & 8 \\
\hline First molar & 7 & 53.8 & 0 & 0.0 & 6 & 46.2 & 13 \\
\hline Second molar & 3 & 100.0 & 0 & 0.0 & 0 & 0.0 & 3 \\
\hline Third molar & 1 & 50.0 & 0 & 0.0 & 1 & 50.0 & 2 \\
\hline
\end{tabular}




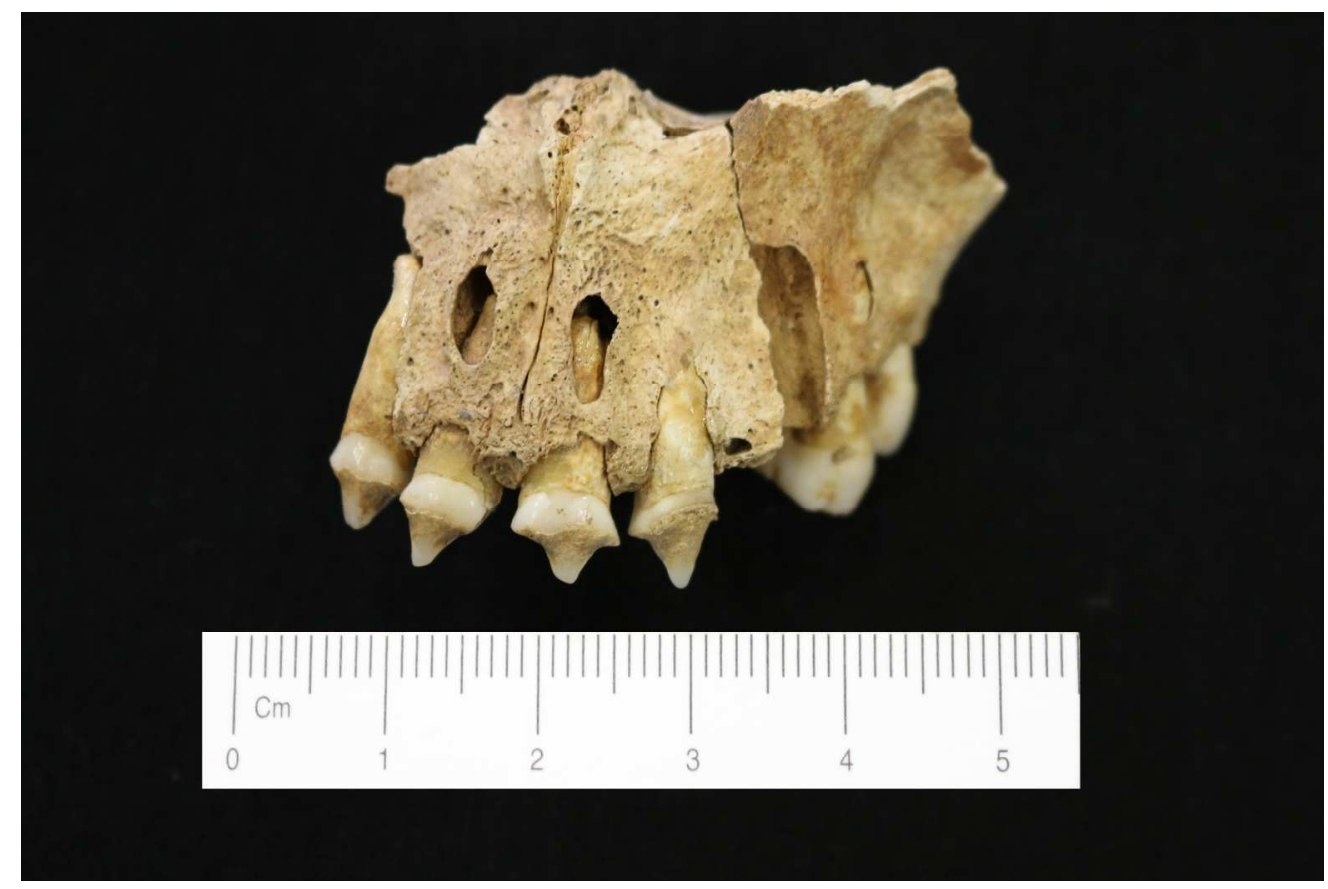

Figure 1. Maxilla (anterior view) of individual no.120 from the deposit of urban waste of the Valle da Gafaria (Lagos, Portugal), with all upper incisors intentionally modified and periapical lesions related to both upper central incisors.

$1930 \times 1286 \mathrm{~mm}(72 \times 72 \mathrm{DPI})$ 


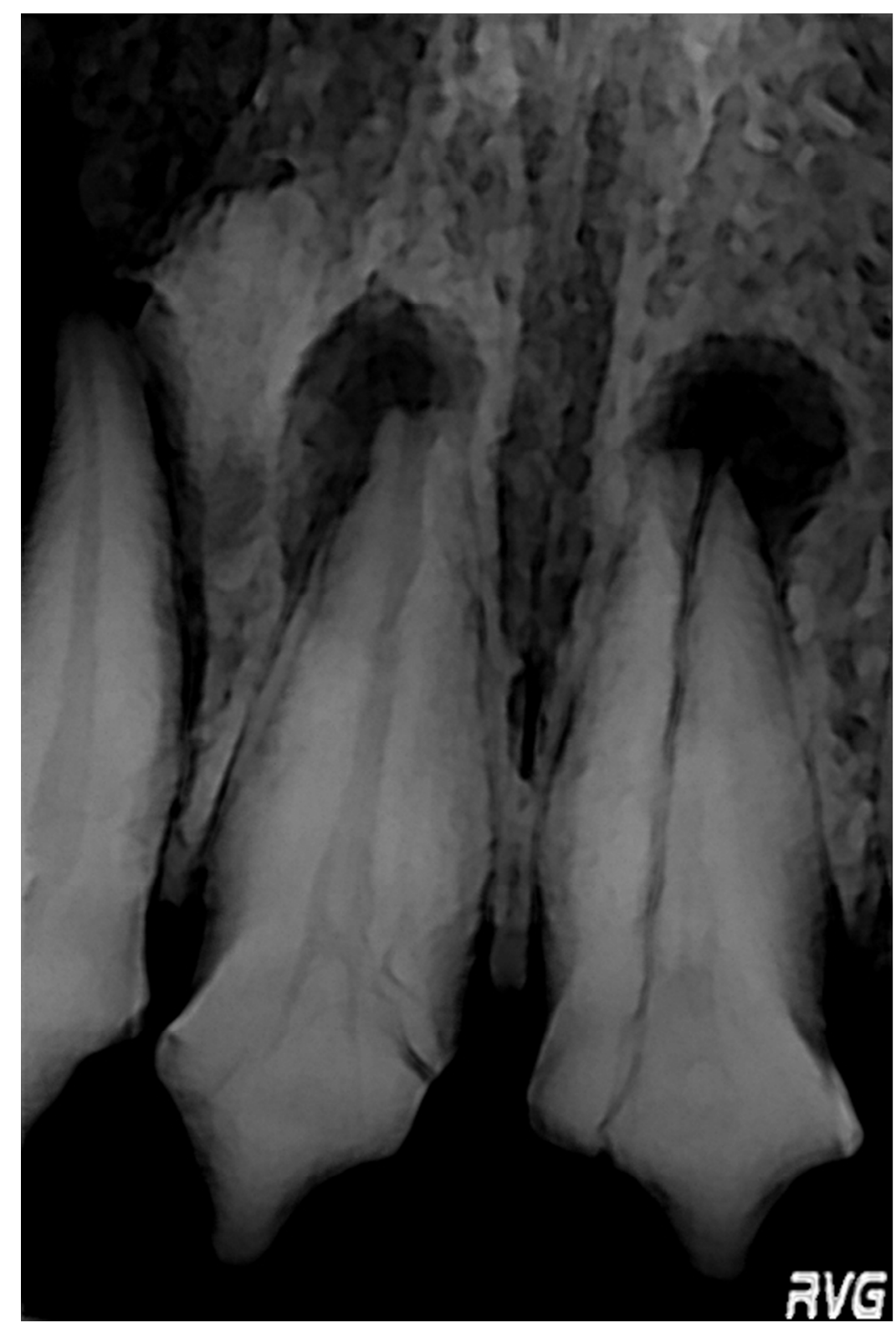

Figure 2. Radiograph of the upper central incisors of individual no.120 from the deposit of urban waste of the Valle da Gafaria (Lagos, Portugal), where it can be observed oval radiolucent areas related to the apices of the modified teeth. Note that both teeth presented post mortem fractures. $500 \times 975 \mathrm{~mm}(26 \times 20 \mathrm{DPI})$ 


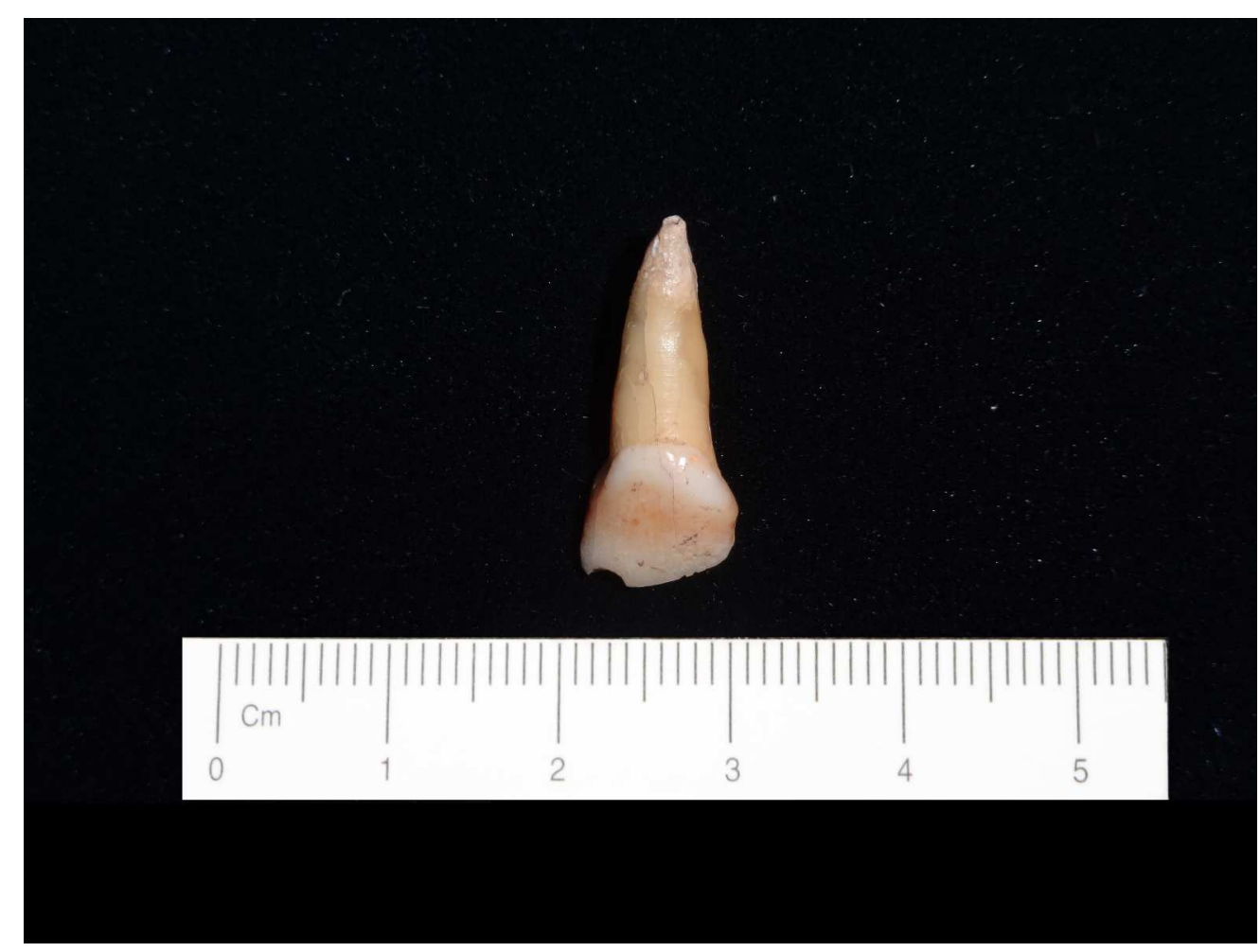

Figure 3. Upper right central incisor (anterior view) of individual no.44 from the deposit of urban waste of the Valle da Gafaria (Lagos, Portugal) with the mesial incisal angle removed. $1625 \times 1219 \mathrm{~mm}(72 \times 72 \mathrm{DPI})$ 


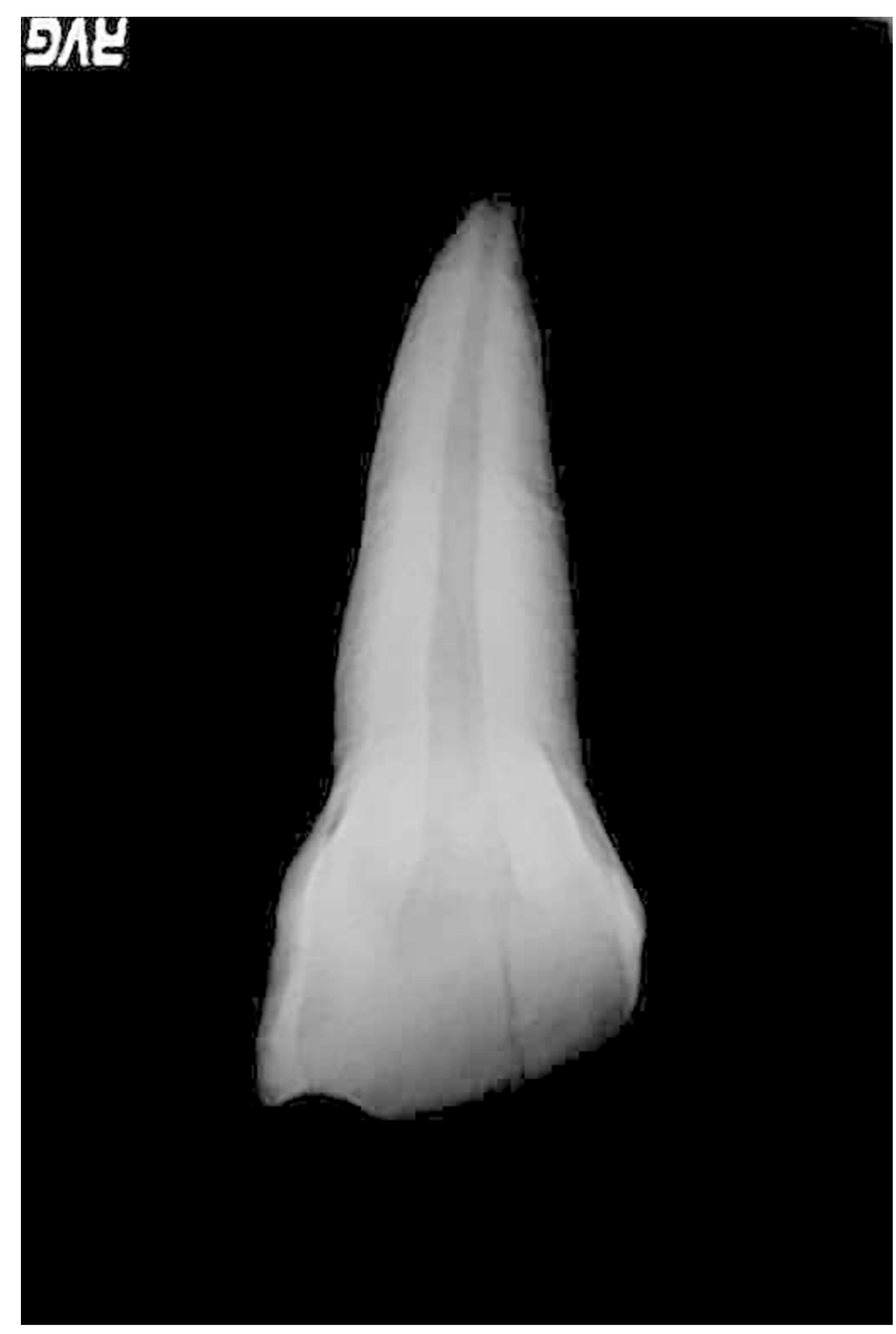

Figure 4. Radiograph of the upper right central incisor of individual no. 44 from the deposit of urban waste of the Valle da Gafaria (Lagos, Portugal), where it can be observed an alteration of the dental pulp morphology on the mesial pulp horn. $500 \times 975 \mathrm{~mm}(26 \times 20 \mathrm{DPI})$ 